\title{
A New Image of Preschool Institutions in Slovenia: Conceptual, Systemic and Curricular Backgrounds
}

LJUBiCA MARJANOVIČ UMEK ${ }^{1}$

$\approx$ Until their conceptual, systemic and substantive reform in the 1990s, preschool institutions in Slovenia were recognised predominantly as care institutions, on the one hand, and as "preparatory institutions" for school or pre-primary school, on the other. This paper presents an analysis of preschool education in Slovenia based on theoretical starting points, international comparative analyses of quality indicators for preschool education and curricular documents, as well as the results of Slovenian and foreign empirical research on early child development and learning. The analysis was conducted from the viewpoint of conceptual, systemic and curricular solutions. In particular, we emphasise the need to update the Curriculum for Preschool and resolve any professional dilemmas related to the efficiency and equity of preschool. In conclusion, we specifically highlight certain possibilities for improvements in Slovenian preschool education.

Keywords: sociocultural theories, quality of preschool, preschool curriculum, efficiency and equity 


\section{Nova podoba slovenskih vrtcev: konceptualna, sistemska in kurikularna ozadja}

LJUBica MARJANOVič UMEK

$\approx$ Slovenski vrtci so bili do konceptualne, sistemske in vsebinske prenove $\mathrm{v}$ devetdesetih letih prejšnjega stoletja na eni strani prepoznani kot prevladujoče varstvene ustanove, po drugi strani pa kot pripravljalnica za šolo oziroma pošolani vrtci. V prispevku na podlagi teoretičnih izhodišč, mednarodnih primerjalnih analiz kazalnikov kakovosti predšolske vzgoje v vrtcih ter kurikularnih dokumentov, izsledkov slovenskih in tujih empiričnih raziskav o zgodnjem razvoju in učenju otrok analiziramo predšolsko vzgojo $\mathrm{v}$ slovenskih vrtcih $\mathrm{z}$ vidika konceptualnih, sistemskih in kurikularnih rešitev. Posebej poudarimo nujnost posodobitve Kurikuluma za vrtce ter strokovne dileme, ki so povezane $\mathrm{z}$ učinkovitostjo in s pravičnostjo vrtcev. V zaključku poudarimo nekatere možnosti za izboljšanje predšolske vzgoje v slovenskih vrtcih.

Ključne besede: sociokulturne teorije, kakovost vrtcev, Kurikulum za vrtce, učinkovitost in pravičnost 


\section{Introduction}

In the decades after the Second World War, especially in the 196os and 1970s, significant positive developments occurred in Slovenian preschool education, going both in the direction of systemic and substantive solutions. Especially with the expansion of the network of preschool institutions in the 1970s, an increasing number of toddlers and children were included in unified public preschool institutions for children of all ages, and the share of children included increased from around $40 \%$ to $50 \%$ between the beginning and the end of the 1980 os. Partly by offering all-day programmes lasting from 8 to 10 hours, preschool institutions successfully followed the relatively high proportion of employed women, taking over childcare while parents were at work. In 1971, preschool institutions were included in their first independent legal act. The initial, predominant role of childcare and the significant medicalisation of preschool institutions changed with the adoption of the Educational Programme for the Upbringing and Care of Preschool Children (Educational programme, 1979), which was the first state-approved programme for preschool institutions, followed by the Educational Programme for Preparing Children for Primary School (Educational programme, 1981), which was intended for children a year before entering school and was compulsory for all children, either in full-year form or in a shortened pre-primary school. Both programmes were based on biologistic and normative views on childhood, or on developmental psychological theories that emphasise developmental milestones or ages at which all or most children acquire certain skills and abilities, and demonstrate expected behaviours. As a result, the programmes defined in detail the objectives and content for each age group of toddlers/children, while at the implementation level the programmes largely followed school work organisation, such as detailed scheduling of planned activities, routines, outdoor activities, sleep and meals. In the Educational Programme for Preparing Children for Primary School (Educational programme, 1981), content related to the acquisition of academic skills dominated.

In the 199os, after Slovenia gained independence, both political and economic changes, as well as changes in governance and new scientific and professional views on education and the implementation of the concept of children's rights, demanded a reform of the entire education system, including preschool education in preschool institutions (Starting points of curriculum renewal, 1996; White paper, 1995).

The purpose of the present paper is to examine how the conceptual, systemic and curricular changes that took place in the second half of the 1990 and 
later followed contemporary, mainly sociocultural views concerning childhood and preschool education, and to understand individual differences in children's development and learning, including factors such as family and the wider social environment. We are also interested in how increasing the percentage of children enrolled in preschool and assessing the quality of preschool education are linked to ensuring the efficiency and fairness of preschool.

\section{Modern conceptions of the child, childhood and preschool}

Newer notions of the child and childhood, learning and education, as well as preschool and its effectiveness and equity are mainly related to the assertion of the sociocultural theory of Vygotsky, Bruner and their contemporaries, such as Karpov (2005), Astington (2000), Olson and Torrance (1996). In the introduction to the first English translation of Vygotsky's book Thinking and Speaking, Bruner wrote: "Vygotsky's conception of development is at the same time a theory of education" (Bruner, 1962, p. viii). Vygotsky described a child who is not a small version of an adult, but rather a person whose thinking works "in a different way, using different means" (Yudina, 2007, p. 4). In one of his last texts, entitled The Problem of Age, he noted: "A child's chronological age is not a credible or reliable criterion for determining the current stage of development" (Vygotsky, 1987, p. 192). At the baseline, he agreed with Piaget that a child's development takes place through developmental stages and that his or her thinking at each subsequent developmental stage is more logical. However, Vygotsky defined developmental stages more flexibly regarding age and emphasised the great influence of the social and cultural environment as well as learning in the individual's development (Vygotsky, 1981, 2010).

Below we present some key highlights from sociocultural theories, such as developmental stages, teaching and learning in the zone of proximal development (ZPD), collaborative learning, learning by imitation and inclusion, symbolic child play, share reading, language, children's communicative and metalanguage abilities, social and cultural context, and the continuum in development and learning or emergent abilities (e.g., Bodrova \& Leong, 2007; 2015; Cheyne \& Tarulli, 2005; van Oers, 2007; Wertsch, 2000). In Slovenia, these theories were more or less successfully integrated into the conceptual and substantive solutions of preschool education in preschool institutions during the reform of preschool in the second half of the 1990s.

The Curriculum for Preschool (Curriculum for preschool, 1999) as a national document for work in preschool institutions, replaced the previously 
valid documents the Educational Programme for the Upbringing and Care in Preschool Children and the Educational Programme for Preparing Children for Primary School. The shift in the conception of the child and childhood and in educational concepts is already reflected in the replacement of the term educational programme with the term curriculum. The term preschool curriculum is broad and in addition to planned activities also includes all other activities and interactions, the spatial and temporal distribution of activities, and the hidden curriculum. Unlike previous documents, the curriculum defines objectives in all six areas (movement, language, art, society, nature and mathematics) for children of the first age group (ages 1 to 3 ) and the second age group (ages 3 to 6). Only certain examples of activities are determined, separately for the first and second age groups. The curriculum is a partially structured document that includes the transition from content-oriented to goal-oriented and processdevelopment planning of educational work (Kroflič, 2001).

The curriculum also incorporates the modern concept of readiness for school, which takes place as a readiness for learning at all ages of toddlers and children (Kruger \& Tomasello, 1996; Marjanovič Umek, 2016; Stipek, 2002; Watson, 1996) and not just the year before entering school as preparation for school. Cheyne and Tarulli (2005) point out that knowledge is generally understood as knowledge formed in emergent processes, and not just at a particular chronological age of children. The results of several empirical studies (e.g., Marjanovič Umek et al., 2006; Marjanovič Umek, 2016; Marxell \& Clifford, 2004; Stipek, 2002) confirm that a child's age is not a key factor that could in itself determine whether or not the child is ready to enter school. There are a number of other factors, among which particular mention should be made of the education of the parents of children included in preschool, the school programme, and the intellectual and language competences of children.

\section{The curriculum and the planning of educational work in preschool}

In the two decades since its introduction, the implementation of the Curriculum for Preschool has not been systematic, methodical or directly monitored (e.g., Pajntar Cotič \& Zore, 2018).

The results of individual studies presented below indicate certain shortcomings in the Curriculum for Preschool at both the written and implemented level, while the comparative analysis of Slovenian and specific new foreign curricula provides an insight into the similarities and differences between curricular documents. 
In an extensive longitudinal study, researchers (Marjanovič Umek \& Fekonja, 2008; Zupančič \& Kavčič, 2007) assessed the impact of preschool on various areas of child development and school performance. The area of language was one of the more critical areas. Children who entered preschool at about one year of age were rated by their parents and preschool teachers as more sociable and with stronger willpower than those who entered preschool later, at about three years of age. At the same time, it emerged that preschool itself did not have a significant impact on children's language development. There were no significant differences in language competence between children who had entered preschool at the age of one and those who had entered preschool at the age of three, except among children whose parents had a low level of education. If rated as a quality institution, preschool compensated for some of the shortcomings in language development of children whose mothers had a low level of education and came from a less supportive family environment. In all four consecutive assessments of children's language, the mother's education was a more important factor than the age of the toddlers/children at the time of enrolment in preschool. Preschool did not have a significant influence on the language of children of mothers with higher education and a favourable family environment, which means that children who were included in preschool at the age of one or later achieved comparable results in language tests.

Relatively large differences between preschool institutions, as well as between groups within the same preschool institutions, are seen in the results obtained in research on the quality of preschool at the process level. Case studies of preschool self-evaluation (Marjanovič Umek et al., 2005) showed that most preschool institutions achieved a medium level of quality, and that only one preschool institution achieved exceptional quality in both the first and second age groups. A lower process quality was assessed particularly in the area of encouraging toddlers' language in classes for the first age period. Educators rarely encouraged infants to speak in routine activities such as eating, preparing for bed and staying outdoors.

The area recognised as the most critical was the promotion of language in toddlers and children, especially in the first age groups, where various activities (e.g., eating, sleep routine, outdoor activities) offered possibilities for language development in toddlers/children.

The question of whether the curriculum should include more modern texts with an in-depth explanation of the conditions, methods and approaches to promote the development and learning of toddlers and children, or whether continuous professional education should be strengthened or undergraduate education of preschool teachers modernised remains open. 
The results of several studies show that additional training of preschool teachers has a significant impact on the quality of educational work with children. Israeli researchers (Korat et al., 2003) studied symbolic play as a context for the development of early literacy in children aged five and a half to six years. The researchers were curious as to how preschool teachers can follow the principles of promoting the development and learning of children in the ZPD when engaging in children's play. For this purpose, the preschool teachers first spent two months educating themselves on topics from Vygotsky's sociocultural theory as well as the implementation of theory in practice. After the period of the training, the researchers observed, recorded and analysed how the preschool teachers guided the symbolic play of children in preschool groups. They found significant changes in the involvement of the preschool teachers in play and its management in the ZPD of children, while the children successfully used several symbolic notations in symbolic play with different content: drawing, and writing numbers and letters. Similarly, Slovenian authors (Marjanovič Umek et al., 2019; Marjanovič Umek et al., 2018) found that preschool teachers successfully incorporated knowledge acquired during a two-month in-service training - specifically, content on language development and learning and early literacy in a broader sociocultural context, the impact of activities such as symbolic play, reading together, speaking with children, and children's language development and early literacy - into additional activities carried out during planned work and the hidden curriculum, with children aged five to six years. Since the study had two basic objectives - to assess the short-term and long-term effects of additional activities in the promotion of early literacy of children - all of the children included in the study were evaluated three times (twice while in preschool, before and immediately after additional activities, and for the third time the following year at the end of the first grade) in several areas of early literacy: graphomotor skills, metalinguistic awareness and storytelling. The results of the study showed, among other things, that the children made significant progress in all areas of early literacy during the first and second evaluations, and that the children who made more progress in graphomotor skills and metalanguage awareness between the first and second evaluations also showed better graphomotor skills and higher metalanguage awareness at the end of the first grade of primary school. The progress was maintained until the end of the first grade. However, this was not true for children's storytelling, as the progress made in this area was not maintained to the end of the first grade of primary school.

Reviewing curricular documents in countries such as Norway (Framework Plan for Kindergartens, 2017), Sweden (National Core Curriculum for Early Childhood Education and Care, 2018), Finland (National Core 
Curriculum for Early Childhood Education and Care, 2019) and Iceland (The Icelandic National Curriculum Guides for Preschools, 2011), which have an organisation comparable to preschool education in Slovenia, i.e., a unified preschool and recognised high-quality preschool education, shows that in these countries curricula are regularly updated at intervals of less than ten years. Curricular documents are structured in different ways and are extensive, but they all include defined basic principles and objectives of preschool education and areas of activity, and specifically highlight play as a method of learning in preschool. The areas of activity are comparable, albeit differently named: language and early literacy; movement and health; the natural, social and cultural environment; and artistic expression. All of these areas are generally also included in the Slovenian curriculum. Based on more detailed comparisons of content and activities in different areas, and taking into account the results of certain aforementioned Slovenian studies, we must point out the weakness of the area of language, which should include some more modern objectives, more detailed placement of language in a broader sociocultural context, and derived connections in the direction of early (also digital) literacy of toddlers/ children. Specialists in specific areas should therefore update the language area in the Curriculum for Preschool, as well as all other areas that were written more than twenty years ago and today no longer fully reflect the development of individual scientific disciplines and the understanding of the early development and learning of toddlers/children.

The issue of children's entry into school or postponement of compulsory schooling, which has been recorded in Slovenia in the last ten years, could also affect changes in the curriculum document, probably in the direction of greater adjustment of objectives and activities to the objectives and standards of knowledge of the first grade or the first triad of primary school. In Slovenia, statistical data on enrolment in preschool and school show that the share of compulsory school children who postpone schooling for one year is growing significantly. For example, five years ago, $6 \%$ of first-graders were seven-year-olds, compared to $11.7 \%$ in the $2019 / 20$ school year (Statistical information: Education, 2020). Adapting the curriculum, in particular adapting the operational objectives for older preschool children to the standards of knowledge in the first grade of primary school, would be a step backwards from the modern notion of children's readiness for school. While in Slovenia the reasons for delayed schooling have not been systematically studied, the authors of studies in other countries recording similar trends in the non-inclusion of children of compulsory school age in school (e.g., Dunlop, 2003; Stipek, 2002; Watson, 1996) note that the implicit theories of parents and preschool teachers about the notion of childhood 
and early learning is largely to blame. These theories concern creating the myth about a happy childhood, about childhood as a time of play, about school being too demanding and "putting pressure" on children, about greater success of children who join school a year later, and the like. However, research findings (e.g., Bickel et al., 1991; Stipek \& Byler, 2001) confirm that postponing schooling for a year does not in itself bring general added value to children's development and performance, and that any initial differences between younger and older pupils in the first grade of primary school even out relatively quickly.

\section{Between the efficiency and equity of preschool}

One of the indicators of equity of preschool in terms of ensuring equal opportunities is the share of children included in preschool. Preschool is not compulsory, but should be accessible to all toddlers/children, regardless of their age or their parents' level of education, including children of migrants, children with special needs, children of working parents and those with one or both parents unemployed, as well as both rural and urban children.

In Slovenia, as in most European countries, the share of children of all ages included in preschool has increased significantly in the last ten years. According to the Statistical Office of the Republic of Slovenia (Statistical information: Education, 2020), in the 2019/20 school year, $82.7 \%$ of children aged one to five were included in Slovenian preschool institutions: $67.5 \%$ of toddlers aged one and two years, and $94.1 \%$ of children aged from four years to school entry. Over the last decade, the inclusion of toddlers/children of all ages has increased by a quarter, inclusion of toddlers up to three years of age by $17.5 \%$, and the inclusion of children aged four and five by $6 \%$. The share of Slovenian toddlers/ children included in preschool compared to other EU countries (Key Data on Early Childhood Education and Care in Europe, 2019), prepared for 2017, shows that in Slovenia a higher proportion of toddlers of up to three years of age are included in preschool than the EU average (34\%) (Figure 1), while the share of children aged from four to school entry included in Slovenia is $92.1 \%$ and is lower than the EU average (95.4\%) (Figure 2). 


\section{Figure 1}

Shares of toddlers up to three years of age included in preschool (data for 2017)

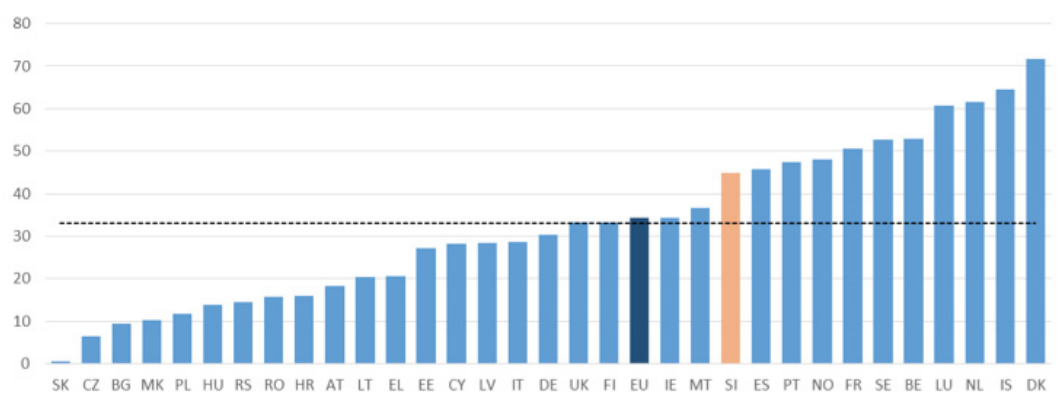

Note. The dotted line shows the recommendation of the Council of Europe for 2020 , i.e., $33 \%$ inclusion of toddlers up to the age of three. Adapted from Key Data on Early Childhood Education and Care in Europe, 2019.

\section{Figure 2}

Shares of toddlers aged from four years to school entry included in preschool (data for 2017)

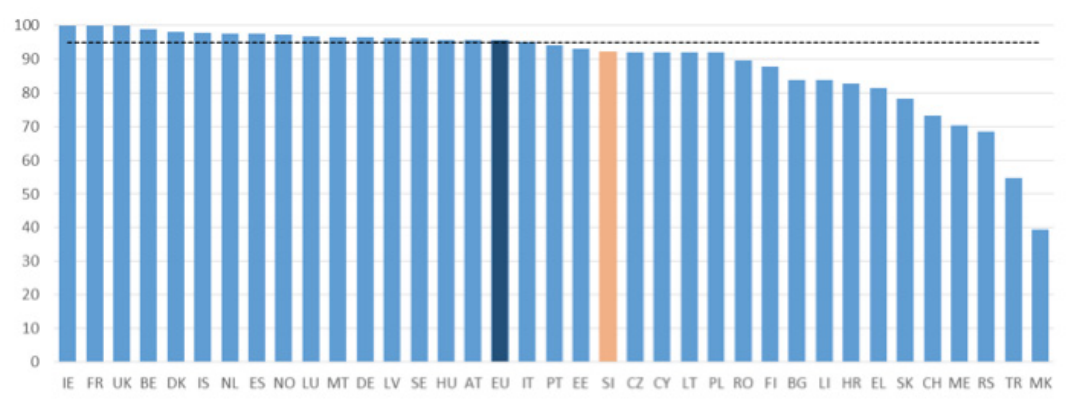

Note. The dotted line shows the recommendation of the Council of Europe for 2020 , i.e., $95 \%$ inclusion of children from the age of four until they enter school. Adapted from Key Data on Early Childhood Education and Care in Europe, 2019.

As can be seen from the comparative data, Slovenia exceeded $33 \%$ inclusion of children in preschool in 2017 , and is nearing $95 \%$ inclusion of children aged from four years to school entry (92.1\% in $2017,94.1 \%$ in 2020 ).

The growing share of toddlers up to the age of three included in preschool is important from several points of view. Neuroscience findings (e.g., Bruer, 1999) confirm that sensitive periods in infant and toddler development are based on early brain development in terms of structure and function, as well as 
on an understanding of the role of education and parenting, which provide a stimulating (symbolic and emotional) environment for early learning. This is therefore the time when the development of infants/toddlers is the most rapid and their learning most efficient; the experience gained during this period is intense, long-term and irreversible. At the same time, both Slovenian and foreign studies (Marjanovič Umek \& Fekonja Peklaj, 2008; Sylva et al., 2004; Zupančič \& Kavčič, 2007) confirm that if toddlers are included in preschool as early as the age of two or three, it has a positive effect on current development and learning as well as on the subsequent development of academic skills and knowledge. In Slovenia, the share of employed parents (especially mothers) of children of all ages is high. In 2017, the employment rate of mothers aged 25 to 54 with one child in Slovenia was $84 \%$ (10\% higher than the EU average), while the share of mothers with two children was $88 \%$ (15\% higher than the EU average), and with three or more children was just over $80 \%$ (23\% higher than the EU average) (Statistične informacije. Materinski dan, 2019). A comparative analysis made for EU and EEA countries (data for 2005) showed that in Slovenia the difference between the share of employed mothers of three-year-olds and the share of three-year-olds included in preschool was among the highest (Early Childhood Education and Care in Europe: Tackling Social and Cultural Inequalities, 2009).

The data given in several studies shows that in Slovenia, as in other EU countries, the share of toddlers/children of all ages included in preschool is gradually increasing. At the same time, the results of studies (although not fully comparable in terms of the children's age and the methodology used) show that in Slovenia there is a trend of reducing differences in the inclusion of toddlers/ children in preschool according to parents' education or family environment.

Data collected in the study Working for Inclusion (2010) relate to the inclusion of toddlers in 2005. Compared to other European countries, there is significant inequality in Slovenia between the shares of toddler mothers with a different level of education, in favour of toddler mothers with higher education. The share of toddlers included in preschool whose mothers have a low level of education was $11 \%$ lower than the share of toddlers whose mothers have a high level of education, whereas in some countries, such as Denmark, Sweden and Finland, the differences were very minor.

Subsequent analysis of statistical data collected in the EU-SILCV database (Podlesek et al., 2010), which includes data for toddlers and older preschool children for 2008, showed, among other things, that the proportion of toddlers included in preschool whose mothers have a low level of education is $20 \%$ lower than the share of mothers with a high level of education, while the share 
of children aged three to six included in preschool whose mothers have a low level of education is $9 \%$ lower than the share of mothers with a high level of education.

The results of a comparative analysis conducted within the OECD (Education at a Glance, 2018) show that in all of the countries involved, the proportions of toddlers (aged three years and younger) included in preschool of mothers with higher education are higher than the proportions of included toddlers of mothers with less than a university degree. The data valid for 2014 shows that Slovenia is one of the countries that has a medium-high share of all toddlers included in preschool, and the difference between the group of toddlers of mothers with higher education and those with less than higher education is small (5\%) and statistically insignificant. High involvement and relatively small differences between groups according to the mother's education are recorded in Norway and Denmark, for example, while extremely low involvement and small differences between groups of mothers according to education are recorded in Slovakia and the Czech Republic. Differences in the inclusion of toddlers according to their parents' education, with a high level of inclusion of toddlers in preschool, are large in the Netherlands and Belgium, for example, while there is low inclusion of toddlers in Austria and Poland. The data also show that the majority of mothers of toddlers with higher education include the toddler in preschool at a younger age than mothers of toddlers with low education. In Slovenia, as in Turkey, the USA and Slovakia, the share of mothers with higher education whose toddlers were included in preschool for two years or more is as much as $18 \%$ higher than the share of toddlers with mothers with a low level of education.

The data collected in a comparative study in which researchers deal with the fairness of school systems (An Unfair Start, 2018) also show a relatively favourable ratio for Slovenia in terms of inclusion in preschool of children from two different groups: children from the fifth of the poorest and the fifth of the richest families. Data for 2016 shows that among the 29 countries surveyed, there are 16 countries in which the difference in the proportion of children aged three years and more belonging to the groups of the poorest and the richest families was statistically significant, always in favour of children from the richest families. In Slovenia, the difference between the two groups of children is relatively small ( $8 \%)$ and is not statistically significant. The differences are the largest (over 40\%) in Croatia and Bulgaria, where the inclusion of children in preschool is low, and the smallest in Iceland and Belgium (from 2 to $3 \%$ ), where the inclusion of children in preschool is high.

In Slovenia, the differences between the shares of toddlers/children included in preschool based on their parents' education are decreasing. As the 
share of toddlers/children of parents with low education is still lower than the share of toddlers/children of parents with higher education, and as the regional distribution of the share of all toddlers/children included in preschool is uneven (The proportion of children included in preschool institutions, 2020), more detailed information needs to be obtained as to why some parents do not choose to include their toddlers/children in preschool. There are probably several factors involved. One of them is the influence of implicit theories of parents about the development and learning of children, because, as a rule, less educated parents also have less knowledge about early development and learning of toddlers/children and the possible support of preschool in their development and learning (e.g., Marjanovič Umek et al, 2016).

One group of children exempt from the preparation and adoption of appropriate systemic (financial, personnel) and substantive solutions in preschool is the group of immigrant children. With only a framework document entitled Guidelines for the Inclusion of Immigrant Children in Preschool Institutions and Schools (2012), working with these children is left entirely to the individual preschool.

A high quality preschool that is recognised as having a positive impact on the current and long-term development and learning of children, particularly those from less supportive family backgrounds, includes both fairness and efficiency. In the last ten years, determining and ensuring the quality of preschool education in preschool institutions has been increasingly linked to efficiency, which is assessed in terms of the benefits of preschool education for the development of human capital or the labour market, or as an investment in people in early life (e.g., Heckman, 2012). A broad-based study entitled the International Early Learning and Child Well-Being Study (IELS), which was developed within the OECD (OECD, 2015), includes internationally comparable assessment of the results of children's learning in five-year-old children in the following areas: selfregulation, oral language/emergent literacy, emergent mathematics/numeracy, executive function, focus of control, and social skills. Several purposes of the study have been determined: providing an in-depth insight into the development and learning of children at an early age, which is the most sensitive age regarding development and learning, as well as regarding influencing the improvement of preschool education programmes; assessing areas identified as predictors of later academic skills and life outcomes through comparisons of the children's results in the IELS with the results of other international comparative knowledge studies, such as PISA, PIRLS and TIMSS, leading to greater efficiency of the global market. Several researchers (e.g., Hočevar \& Kovač Šebart, 2018; Moss et al., 2016; Moss \& Urban, 2017; Urban, 2017) have responded critically to the standardised 
assessment process of five-year-olds, as well as to the definition of early learning outcomes and their connection with the learning outcomes of PISA, which, in the authors' opinion, directly or indirectly leads to the identification of only one "real" teaching process in preschool (or one real teaching pedagogy), direct preparation of children for assessment of learning areas as defined in the IELS and in the direction of the scholarisation of preschool. Urban (2017) specifically points out that with the IELS study, the OECD deviated from the starting points and guidelines published in the publications Starting Strong I (OECD, 2001) and Starting Strong II (OECD, 2006), which highlight both the need to assess the quality of preschool education in conjunction with national curricula and the diversity in the definition of quality indicators and approaches for the self-evaluation of preschool institutions.

Once the Curriculum for Preschool was introduced in Slovenia, the conceptualisation of the quality of preschool education followed. Taking into account the concept of the Slovenian curriculum, Marjanovič Umek et al. (2002) formed a comprehensive model of the quality of preschool education in preschool institutions, which includes three levels of quality: structural (e.g., organisation of work and life in preschool), indirect (e.g., collaboration between employees) and process (e.g., direct educational work with children).The authors, who emphasised the importance of process quality in the model, also designed assessment aids for assessing indicators at this level (observation sheets, assessment scales, screening tests and partially structured interviews with children) (Marjanovič Umek et al., 2002; Marjanovič Umek et al., 2005). The solutions obtained in the project were later not recognised at the national level as systemic solutions or as a supplement to the curriculum (both possible solutions are recognised abroad, e.g., in England, Norway and Iceland); however, several other projects followed that conceptualised the quality of preschool education within the broader framework of identifying and ensuring the quality of the entire education system and to a large extent under the influence of the school environment and the assessment of pupil's knowledge standards. In the project Kakovost v izobraževanju (Quality in Education, 2019), which has taken place in Slovenia in recent years under the auspices of the National School of Leadership in Education, preschool institutions have again, at least partly, re-established recognition of and connection with the Curriculum for Preschool. As quality standards, the project defines results (outcomes) in the development and learning of children in the context of process quality in preschool; for example, children develop language competences; children develop emergent literacy.

In Slovenia, the concept of determining and ensuring the quality of preschool at the national level is still not integrated into systemic and substantive 
solutions, and consequently lacks a basis for directing preschool education in preschool institutions, at the level of both structural and process quality. Since even the structural quality indicators - the size of preschool groups, the ratio between professional staff and toddlers/children in the group, and the education of professional staff in preschool, which were defined as universal in the comparative studies Starting Strong I (2001) - are not properly integrated into the overall concept of quality and the understanding of the relationship between structural and process quality in Slovenia (e.g., Kajonius \& Kazeni, 2016), individual indicators have been the subject of political discussions and consequent attempts to reduce financial investment funds for preschool education in preschool institutions.

\section{Conclusion}

Based on the findings of international comparative analyses of preschool quality indicators and curricular documents, as well as Slovenian and foreign research on the short-term and long-term effects of preschool on children's development and learning, Slovenian preschool can be assessed as high quality. Nevertheless, some solutions - conceptual, systemic and substantive - are less appropriate and need to be supplemented or updated, while others are even missing and need to be included in legislation, regulations or curricular documents.

More than twenty years have passed since the adoption of the Curriculum for Preschool, so there is a need to review and update both the structure and content of the curriculum, particularly certain principles, preschool activity fields and specific objectives in activity fields. In addition to updating the objectives relating to the promotion of children's development and learning in various areas, the curriculum should also pursue long-term objectives, such as the development of an autonomous, responsible, critical and creative individual. As in its preparation in 1999, the updating of the curriculum should be based on an interdisciplinary approach that allows for a high level of professionalism in the preparation of objectives and activities in individual fields, while at the same time considering the target group of toddlers and children in early childhood. All proposed updates should also be examined by preschool educators, managers and counsellors.

The question of the increase in the percentage of school-age children not included in school in Slovenia over the past ten years also needs to be examined. If professional answers to this question cannot be provided, it may be that the renewal of the Curriculum for Preschool will lead to a greater adaptation of 
preschool to school or more "schoolwork", either in all preschool age groups or in the final year before children enter school (the reintroduction of the school preparation programme). Such starting points would mean a significant departure from the contemporary understanding of transitions between preschool and school, and a departure from understanding the characteristics of early development and learning in toddlers and children.

The question concerning the quality of preschool education also remains open, both on a conceptual and systemic level. As quality indicators are not unambiguously defined at the national level, there is no systemic (self-) evaluation of educational work in preschool practice. (Self-)evaluation with a relatively open curriculum is a necessary basis for maintaining and developing quality work with preschool children as an institution and in preschool groups.

Certain structural quality indicators, particularly the number of children in toddler groups and the ratio between the number of adults and children in all age groups, are some of the obstacles to better quality educational work with toddlers and children. This involves the connection of structural and process quality indicators, which is reflected, for example, in the frequency and quality of social interactions, and communication between adults and toddlers/ children, and consequently in providing a more-or-less safe and stimulating learning environment in preschool.

Given the many new insights into the early development and learning of children, which either directly or indirectly affect the quality of educators' work with children, there is a need to include more content in the field of curricular theories in terms of in-service preschool teacher education, development and learning in preschool children, and process quality assessment of preschool groups.

\section{References}

An unfair start. Inequality in children's education in rich countries. (2018). UNICEF. Astington, J. W. (Ed.) (200o). Minds in the making. Blackwell Publishers.

Barnett, W. S. (2008). Preschool education and its lasting effects: Research and policy implications.

Retrieved from: http://epicpolicy.org/publication/preschooleducation.

Bickel, D., Zigmond, N., \& Strayhorn, J. (1991). Chronological age at entrance to first grade: Effects on elementary school success. Early Childhood Research Quarterly, 6(2), 105-117.

Bodrova, E., \& Leong, D. J. (2007). Playing for academic skills. Children in Europe (special publication Rediscovering Vygotsky), 10-12.

Bodrova, E., \& Leong, D. J. (2015). Vygotskian and post-Vygotskian views on children's play.

American Journal of Play, 7(3), 371-388. 
Bruer, J. T. (1999). The myth of the first three years. A new understanding of early brain development and lifelong learning. Free Press.

Bruner, J. (1962). Introduction to L. S. Vygotsky. In L. S. Vygotsky (Ed.), Thought and language (pp. v-xiii). MIT Press.

Chyne, J. A., \& Tarulli, D. (2005). Dialogue, difference and voice in zone of proximal development. In H. Daniels (Ed.), An introduction to Vygotsky (pp. 125-149). Routledge.

Curriculum for preschool [Kurikulum za vrtce]. (1999). Ministry of Education, Science and Sport,

National Education Institute Slovenia.

Dunlop, A. W. (2003). Bridging early educational transitions in learning through children's agency.

European Early Childhood Educational Research Journal, Transitions, 11(1), 67-86.

Early childhood education and care in Europe: Tackling social and cultural inequalities. (2009).

Eurydice.

Education at a glance. (2018). OECD.

Educational programme for the upbringing and care of preschool children [Vzgojni program za vzgojo in varstvo predšolskih otrok]. (1979). National Education Institute Slovenia.

Educational programme for preparing children for primary school [Vzgojni program priprave otrok na osnovno šolo]. (1981). National Education Institute Slovenia.

Framework plan for kindergartens. (2017). Norwegian Directorate for Education and Training. Guidelines for the inclusion of immigrant children in preschool institutions and schools [Smernice za vključevanje otrok priseljencev v vrtce in šole]. (2012). National Education Institute Slovenia.

Heckman, J. J. (2012). The development origins of health. Health Economics, 21, 24-29.

Hočevar, A., \& Kovač Šebart, M. (2018). Skrb za učinkovitost predšolske vzgoje ali »mehki inženiring « delovne sile v prihodnosti? [Concern for the effectiveness of preschool education or "soft engineering" of the workforce of the future?]. Sodobna pedagogika, 69(4), 6-29.

International early learning and child well-being study (IELS). (2015). http://www.oecd.org/edu/ school/international-early-learning-and-child-well-being-study.htm

Kajonius, P. J., \& Kazeni, A. (2016). Structure and process quality as predictors of satisfaction with elderly care. Health and Social Care in Community, 24(6), 699-707.

Karpov, Y. V. (2005). The neo-Vygotskian approach to child development. Cambridge University Press.

Key data on early childhood education and care in Europe. (2019). Education, Audiovisual and Culture Executive Agency.

Korat, O., Bahar, E., \& Snapir, M. (2003). Sociodramatic play as opportunity for literacy development: The teacher's role. The Reading Teacher, 56(4), 386-393.

Kroflič, R. (2001). Temeljne predpostavke, načela in cilji kurikula za vrtce [Basic assumptions, principles and goals of the preschool curriculum]. In L. Marjanovič Umek (Ed.), Otrok $v$ vrtcu: Priročnik h kurikulu za vrtce (pp. 7-25). Obzorja.

Kruger, A. C., \& Tomasello, M. (1996). Cultural learning and learning culture. In D. R. Olson \& N.

Torrance (Ed.), Education and human development (pp. 369-387). Blackwell Publishers.

Marjanovič Umek, L. (2016). Pripravljenost otrok za vstop v šolo: vpliv starosti in drugih 
individualnih in okoljskih dejavnikov [Children's school readiness: The impact of age and other individual and environmental factors]. Šolsko svetovalno delo, 2o(3/4), 4-12.

Marjanovič Umek, L., \& Fekonja Peklaj, U. (2008). Sodoben vrtec: možnosti za otrokov razvoj in zgodnje učenje [Modern preschool: Opportunities for children's development and early learning]. Scientific Research Institute of the Faculty of Arts.

Marjanovič Umek, L., Fekonja, U., \& Bajc, K. (Ed.), 2005. Pogled v vrtec [Insight into preschool]. National Examinations Centre.

Marjanovič Umek, L., Fekonja, U., \& Bajc, K. (2006). Dejavniki otrokove pripravljenosti za šolo [Factors of children's school readiness]. Psihološka obzorja, 15(2), 31-51.

Marjanovič Umek, L., Fekonja, U., \& Hacin, K. (2019). Dodatni program za spodbujanje zgodnje pismenosti v vrtcu: Kratkoročni in dolgoročni učinki [The supplementary programme to support early literacy in preschool: Short- and long-term outcomes]. Sodobna pedagogika, 7o(3), 10-23. Marjanovič Umek, L., Fekonja, U., Kavčič, T., \& Poljanšek, A. (Eds.) (2002). Kakovost v vrtcih [Quality in preschool institutions]. Scientific Research Institute of the Faculty of Arts. Marjanovič Umek, L., Fekonja Peklaj, U., Tašner, V., \& Sočan, G. (2016). Govor otrok: Vpliv nekaterih sociokulturnih dejavnikov družinskega okolja [Children's language: The influence of some sociocultural factors of the family environment]. In T. Devjak \& I. Saksida (Eds.), Bralna pismenost kot izziv in odgovornost (pp. 43-68). Pedagoška fakulteta UL.

Marjanovič Umek, L., Hacin, K., \& Fekonja, U. (2018). Children's early literacy: The effect of preschool and family factors. Sodobna pedagogika, 69(1), 112-125.

Moss, P., Dahlberg, G., Greishaber, S., Mantovani, S., May, H., Pence, A., Rayna, S., Blue Swadener, B., \& Vanderbroeck, M. (2016). The Organisation for Economic Co-operation and Development's international early learning study: Opening for debate and contestation. Contemporary Issues in Early Childhood, $17(3), 343-51$.

Moss, P., \& Urban, M. (2017). The OECD international early learning study: What happened next. Contemporary Issues in Early Childhood,18(2), 250-258. https://doi.org/10.1177/1463949117714086 Maxwell, K. L., \& Clifford, R. M. (2004). School readiness assessment. Young Children,1 -10. http:// www.medicosescolares.com.ar/articulos/299_Maxwell2004.pdf National core curriculum for early childhood education and care. (2018). Swedish National Agency for Education.

National core curriculum for early childhood education and care. (2019). Finnish National Agency for Education.

OECD. (2001). Starting strong I. Early childhood education and care. OECD.

OECD. (2006). Starting strong II. Early childhood education and care. OECD.

OECD. (2015). Call for tenders: International early learning study. http://www.oecd.org/

callsfortenders/CfT 100001420 International Early Learning Study.pdf

Olson, D. R., \& Torrance, N. (Eds.) (1996). Education and human development. New models of learning, teaching and schooling. Blackwell Publishers.

Pajntar Cotič, J., \& Zore, N. (2018). Priporočila za uspešen prehod otrok iz vrtca $v$ šolo 
[Recommendations for the successful transition of children from preschool to school]. Zavod RS za šolstvo. https://www.zrss.si/zrss/wp-content/uploads/priporocila-za-vrtce_prehod_9-julij-2018.pdf Quality in education. Quality in preschool institutions and schools collection [Kakovost v izobraževanju. Zbirka Kakovost v vrtcih in šolah]. (2019). National School of Leadership in Education.

Podlesek, A., Marjanovič Umek, L., \& Fekonja Peklaj, U. (2010). Izračun o deležih otrok, vključenih v vrtec, glede na izobrazbo njihovih staršev [Calculation of the Shares of children included in preschool, according to the education of their parents]. Unpublished material. Faculty of Arts in Ljubljana. Starting points of curriculum renewal [Izhodišča kurikularne prenove]. (1996). National Curriculum Council.

Statistical information: Education [Statistične informacije. Izobraževanje]. (2020). Statistical Office of Slovenia.

Statistical information. Mother's day [Statistične informacije. Materinski dan]. (2019). Statistical Office of Slovenia.

Stipek, D. (2002). At what age should children enter kindergarten? A question for policy makers and parents. Society for Research and Child Development Social Policy Report, 16(2), 3-16.

Stipek, D., \& Byler, P. (2001). Academic achievement and social behaviors associated with age of entry into kindergartens. Journal of Applied Development Psychology, 22(2), 175-189.

Sylva, K., Melhuish, E., Samons, P., Siraj-Blatchford, I., \& Taggart, B. (2004). The effective provision of preschool education (EPPE) project: Findings from pre-school to the end of key stage 1. http://www. dotwaidecentre.org.au/prf/EPPE.prf

The Icelandic national curriculum guide for preschool. (2011). Ministry of Education, Science and Culture.

The proportion of children included in preschool institutions, by municipality of residence and age groups, Slovenia, annually [Delež otrok, vključenih v vrtce, po občini stalnega prebivališča in starostnih obdobjih, Slovenija, letno poročilo]. (2020). https://podatki.gov.si/dataset/surso971412s Urban, M. (2017). We need meaningful systemic evaluation, not a preschool PISA. Global Education Review, 4(2), 18-24.

White paper on education in the Republic of Slovenia [Bela knjiga o vzgoji in izobraževanju v Republiki Sloveniji]. (1995). Ministrstvo za šolstvo in šport.

Van Oers, B. (2007). In the zone. Children in Europe (special publication Rediscovering Vygotsky), 14-15.

Vigotski, L. S. (2010). Mišljenje in govor [Thinking and speaking]. Pedagoška fakulteta UL. Vygotsky, L. S. (1981). The genesis of higher mental development. In J. V. Wertsch (Ed.), The conception of activity in Soviet psychology (pp. 144-188). Sharpe.

Vygotsky, L. S. (1987). The problem of age. In R. W. Rieber \& A. S. Carton (Eds.), The collected works of L. S. Vygotsky. Problem of general psychology (Vol. 5, pp. 187-205). Springer.

Watson, R. (1996). Rethinking readiness for learning. In D. R. Olson \& N. Torrance (Eds.), Education and human development (pp. 148-72). Blackwell Publishers. 
Wertsch, J. V. (2000). Vygotsky's two minds on the nature of meaning. In C. D. Lee \& P. Smagorinsky (Eds.), Vygotskian perspectives on literacy research. Constructing meaning through collaborative inquiry (pp. 19-30). Cambridge University Press.

Working for inclusion: An overview of European Union early years services and their workforce (2010). http://www.childreninscotland.org.uk/docs/WFI_Res_Briefing-Jamo.pdf

Yudina, E. (2007). Lev Vygotsky and his cultural-historical approach. Children in Europe (special publication Rediscovering Vygotsky), 3-4.

Zupančič, M., \& Kavčič, T. (2007). Otroci od vrtca do šole: Razvoj osebnosti in socialnega vedenja ter učna uspešnost prvošolcev [Children from preschool to school: Personality and social behaviour development and learning success of first graders]. Scientific Research Institute of the Faculty of Arts.

\section{Biographical note}

Ljubica Marjanovič Umek, $\mathrm{PhD}$, is a professor emeritus University of Ljubljana. She is a developmental psychologist, researching mainly in the field of early language and cognitive development, development of early literacy and play, family literacy as well as the quality of preschool and the transition into primary school. 